\title{
GAMBARAN INDEKS MASSA TUBUH (IMT) JAMAAH MESJID AL- FATAH MALALAYANG
}

\author{
${ }^{1}$ Trigisa Lasabuda \\ ${ }^{2}$ Pemsi M. Wowor \\ ${ }^{2}$ Yanti Mewo
}

\author{
${ }^{1}$ Kandidat Skripsi Fakultas Kedokteran Universitas Sam Ratulangi Manado \\ ${ }^{2}$ Bagian Farmakologi Fakultas Kedokteran Universitas Sam Ratulangi Manado \\ Email: gizzaaizaki@gmail.com
}

\begin{abstract}
Obesity is one manifestation of nutritional problems, which need attention. Obesity is a state of excess body fat in absolute terms and relative. In 2000, the Directorate of Community Nutrition Ministry of Health recorded a total population of Indonesia are categorized as obese estimated 76.7 million (17.5\%). Many factors play a role in the occurrence of obesity are largely an interaction between genetic factors and environmental factors, such as physical activity, social, economic, and nutrition. The obesity increases the risk of cardiovascular disease because its related with the metabolic syndrome or insulin resistance syndrome or / hyperinsulinemia, glucose intolerance / diabetes mellitus (DM), dyslipidemia, hypertension and other. This study uses a quantitative research design and crosssectional approach which takes place from July to August, 2015. The total sample of 20 people were taken to the al-Fatah mosque Malalayang aged 9-21 years. The results of the research showed that respondent with weight less amounted to 8 respondent, respondents with normal weight is 10 respondents and it was the highest, respondent with pre-obesity is only one respondent, while respondent with obesity II also only 1 respondents. Conclusion: The results of this study concluded that the image of the body mass index (BMI) mosque al - Fatah Malalayang respondents with less weight have percentage of $40 \%$, respondents with normal weight have a percentage of $45 \%$, respondents with more weight percentage of $15 \%$, the respondents with pre-obese weight have percentage of $5 \%$, and the respondent with weight obesity II have a percentage of $10 \%$.
\end{abstract}

Keywords: obesity, body mass index (BMI), diabetes mellitus (DM).

\begin{abstract}
Abstrak: Obesitas merupakan salah satu manifestasi dari masalah gizi lebih, yang perlu mendapatkan perhatian. Pada tahun 2000, Direktorat Bina Gizi Masyarakat Departemen Kesehatan RI mencatat jumlah penduduk Indonesia yang masuk kategori obesitas diperkirakan 76.7 juta (17.5\%) . Banyak faktor yang berperan dalam terjadinya obesitas yang sebagian besar merupakan interaksi antara faktor genetik dengan faktor lingkungan, antara lain aktivitas fisik, sosial ekonomi, dan nutrisi. Keadaan obesitas meningkatkan risiko penyakit-penyakit kardiovaskular karena keterkaitanya dengan sindrom metabolik atau atau sindrom resistensi insulin/hiperinsulinemia, intoleransi glukosa/Diabetes Melitus (DM), dyslipidemia, hipertensi dan lainnya. Penelitian ini menggunakan desain penelitian kuantitatif dan pendekatan cross sectional yang berlangsung dari Juli - Agustus 2015. total sampel berjumlah 20 orang yang diambil pada jamaah Masjid Al- Fatah Malalayang yang berusia 19 - 21 tahun. Berdasarkan hasil penelitian didapatkan bahwa responden yang memiki berat badan kurang berjumlah 8 responden, responden dengan berat badan normal 9 responden dan merupakan yang terbanyak, responden dengan pra obesitas 1 responden, sedangkan responden dengan badan obesitas II 2 responden. Simpulan: Dari hasil penelitian dapat disimpulkan bahwa gambaran Indeks Massa tubuh (IMT) masjid al - fatah malalayang responden dengan berat badan kurang memiliki persentase sebesar $40 \%$, responden dengan berat badan normal memiliki persentase sebesar $45 \%$, responden dengan berat badan lebih memiliki persentase sebesar $15 \%$, responden
\end{abstract}


dengan berat badan pra obesitas memiliki persentase sebesar 5\%, Responden dengan berat badan obesitas II memiliki persentase sebesar 10\%.

Kata kunci: obesitas, indeks massa tubuh (IMT), diabetes mellitus (DM).

Obesitas merupakan salah satu manifestasi dari masalah gizi lebih, yang perlu mendapatkan perhatian. Obesitas merupakan keadaan berlebihnya lemak tubuh secara absolut maupun relatif. ${ }^{1}$ Data menunjukkan bahwa prevalensi obesitas di Amerika Serikat pada orang dewasa berumur 20 tahun atau lebih sebesar $32,2 \%$ pada pria dan $35,5 \%$ pada wanita. ${ }^{2}$ Pada tahun 2000, Direktorat Bina Gizi Masyarakat Departemen Kesehatan RI mencatat jumlah penduduk Indonesia yang masuk kategori obesitas diperkirakan 76.7 juta (17.5\%) dan penderita obesitas berjumlah lebih dari 9.8 juta (4.7\%) penduduk dari jumlah 210 juta penduduk pada tahun itu. ${ }^{3}$ Banyak faktor yang berperan dalam terjadinya obesitas yang sebagian besar merupakan interaksi antara faktor genetik dengan faktor lingkungan, antara lain aktivitas fisik, sosial ekonomi, dan nutrisi. ${ }^{4}$ Keadaan obesitas meningkatkan risiko penyakit-penyakit kardiovaskular karena keterkaitanya dengan sindrom metabolik atau atau sindrom resistensi insulin/hiperinsulinemia, intoleransi glukosa/Diabetes Melitus (DM), dyslipidemia, hipertensi dan lainnya. ${ }^{5}$ Pada prinsipnya, obesitas terjadi karena asupan energi yang masuk lebih besar dibanding yang keluar sehingga terjadi kelebihan energi dalam bentuk jaringan lemak. ${ }^{6}$ Indeks Massa Tubuh (IMT) atau Body Mass Index (BMI) merupakan alat atau cara yang sederhana untuk memantau status gizi orang dewasa, khususnya yang berkaitan dengan kekurangan dan kelebihan berat badan. Rumusan perhitungan IMT adalah sebagai berikut. IMT

$$
=\frac{\text { Berat Badan }(\mathrm{kg})}{\text { Tinggi Badan }(\mathrm{m}) \times \text { Tinggi Badan }(\mathrm{m})}
$$

Penatalaksanaan obesitas terdiri dari pembatasn kalori yang disebut terapi medik dan olahraga. ${ }^{7}$ Untuk obesitas sasaran awal yang ingin diapai adalah menurunkan berat badan 5-10\% dari berat badan awal. Dengan penurunan berat badan awal tersebut dapat mengurangi faktor resiko koroner. $^{8}$

Tabel 1. Klasifikasi Berat Badan Lebih dan Obesitas pada Orang Dewasa Berdasarkan IMT Menurut Kriteria Asia Pasifik

\begin{tabular}{cc}
\hline Klasifikasi & IMT $\left(\mathrm{Kg} / \mathrm{m}^{2}\right)$ \\
\hline Underweigth & $<18.5$ \\
Normal & $18.5-22.9$ \\
Overweight & $>23,0-24,9$ \\
Obesitas I & $25,0-29,9$ \\
\hline Obesitas II & $\geq 30,0$
\end{tabular}

\section{METODE PENELITIAN}

Penelitian yang di lakukan berupa penelitian deskriptif yang menggunakan desain Cross sectional. Penelitian dilakukan di di Masjid Al- Fatah Kampung Baru Kelurahan Malalayang, Kecamatan Malalayang, Kota Manado, Sulawesi Utara. Penelitian ini dilakukan selama 2 bulan sejak persiapan sampai penyusunan laporan yaitu pada bulan Juli 2015 sampai Agustus 2015. Yang menjadi sampel dalam penelitian ini disebut responden yang berjumlah 20 orang. Responden adalah para Jamaah Mesjid Al-Falah malalayang.

\section{HASIL DAN BAHASAN}

Tabel 2. Karakteristik Responden Berdasarkan Jenis Kelamin

\begin{tabular}{cccc}
\hline No & $\begin{array}{c}\text { Jenis } \\
\text { Kelamin }\end{array}$ & $\mathrm{n}$ & $\%$ \\
\hline 1 & Laki- laki & 11 & 55 \\
2 & Perempuan & 9 & 45 \\
\hline & Jumlah & 20 & 100 \\
\hline
\end{tabular}


Dari Tabel 2 dapat dilihat bahwa jemlah responden dari penelitian ini berjumlah 20 responden yang terdiri dari 11 laki- laki dan 9 perempuan selanjutnya dilakukan pengukuran berat dan tinggi badan. Berikut Tabel 3 distribusi umur responden.

Tabel 3. Distribusi Umur Responden

\begin{tabular}{ccccc}
\hline $\begin{array}{c}\text { Umur } \\
\text { (Tahun) }\end{array}$ & L & P & $\begin{array}{c}\text { Jumlah } \\
\text { Responden } \\
\text { (Orang) }\end{array}$ & $\begin{array}{c}\text { Persen } \\
(\%)\end{array}$ \\
\hline 19 & 4 & 6 & 10 & 50 \\
$19-20$ & 5 & 5 & 7 & 35 \\
$21^{>}$ & 2 & 1 & 3 & 15 \\
\hline Jumlah & 11 & 9 & 20 & 100 \\
\hline
\end{tabular}

Dilihat pada Tabel 3 bahwa responden dengan umur 18 tahun terbanyak dengan 10 responden yang terdiri dari 4 laki- laki dan 6 perempuan, kemudian umur 19- 20 tahun 7 responden yang terdiri dari 5 laki- laki dan 2 perempuan, sedangkan umur 21 tahun ke atas 3 responden yang terdiri dari 2 laki- laki dan 1 perempuan.

Tabel 4. Distribusi Responden berdasarkan IMT

\begin{tabular}{|c|c|c|c|}
\hline No & Kriteria & $\mathrm{n}$ & (\%) \\
\hline 1 & $\begin{array}{l}\text { Berat Badan Kurang » } \\
\text { IMT/BMI Kurang Dari } \\
18,5\end{array}$ & 8 & 40 \\
\hline 2 & $\begin{array}{l}\text { Berat Badan Normal » } \\
\text { IMT/BMI 18,5 - 22,9 }\end{array}$ & 9 & 45 \\
\hline 3 & $\begin{array}{l}\text { Berat Badan Lebih » } \\
\text { IMT/BMI Lebih Dari } 23\end{array}$ & 3 & 15 \\
\hline 4 & $\begin{array}{l}\text { Berat Badan Pra } \\
\text { Obesitas » IMT/BMI } 23 \\
\text { - 24,9 }\end{array}$ & 1 & 5 \\
\hline 5 & $\begin{array}{l}\text { Berat Badan Obesitas I » } \\
\text { IMT/BMI } 25 \text { - 29,9 }\end{array}$ & 0 & 0 \\
\hline \multirow[t]{2}{*}{6} & $\begin{array}{l}\text { Berat Badan Obesitas II } \\
\text { » IMT/BMI Lebih Dari } \\
30\end{array}$ & 2 & 10 \\
\hline & Jumlah & 20 & 100 \\
\hline
\end{tabular}

Dari Tabel 5 dapat dilihat bahwa responden yang memiki berat badan kurang berjumlah 8 responden, responden dengan berat badan normal 9 responden dan merupakan yang terbanyak, responden dengan pra obesitas 1 responden, sedangkan responden dengan badan obesitas II 2 responden. Pada penelitian ini ditemukan nilai rata-rata dari IMT jamaah Mesjid Al-Fatah Malalayang adalah 20,19 dengan standar deviasinya adalah 4,5 dan indeks BMI tertinggi adalah 36.7 dan yang terendah adalah 17.1. Dari hasil penelitian deskriptif dengan pendekatan cross sectional yang mengambil sampel berjumlah 20 orang di Masjid Al- Fatah Kampung Baru Kelurahan Malalayang, Kecamatan Malalayang, Kota Manado pada periode Juli-Agustus berdasarkan jenis kelamin pada responden perempuan ditemukan Obesitas II 2 orang (10\%), dan pada laki-laki berat badan pra obesitas 1 orang (5\%). Berdasarkan umur diketahui responden yang paling banyak adalah dengan umur 18 tahun (50\%), kemudian umur 19-20 tahun 7 responden (35\%), sedangkan umur 21 tahun keatas 3 responden (15\%). Pada penelitian ini juga ditemukan responden dengan berat badan kurang berjumlah 8 orang (40\%). Banyaknya responden yang memiliki berat badan kurang disebabkan karena penelitian yang dilakukan bulan Juli - Agustus bertepatan dengan bulan ramadhan dimana para responden menjalani ibadah puasa sehingga mengalami penurunan berat badan.

\section{SIMPULAN DAN SARAN}

Berdasarkan penelitian yang dilakukan pada bulan Juli 2015 Masjid Al- Fatah Kampung Baru Kelurahan Malalayang, diperoleh kesimpulan yaitu, Responden dengan berat badan kurang memiliki persentase sebesar $40 \%$. responden dengan berat badan normal memiliki persentase sebesar 45\%. Responden dengan berat badan lebih memiliki persentase sebesar $15 \%$. Responden dengan berat badan pra obesitas memiliki persentase sebesar $5 \%$. Responden dengan berat badan obesitas II memiliki persentase sebesar $10 \%$. Sebaiknya untuk berat badan lebih dan obesitas dilakukan pembatasan kalori yaitu terapi medik dan olahraga. Biasanya, 
pembatasan kalori cukup dilakukan dengan mengurangi jumlah kalori sebesar 500 kilokalori dari jumlah yang biasa dikonsumsi sebelumnya. peningkatan aktivitas tubuh dapat dilakukan dengan jalan cepat $3 \times 50$ menit/minggu atau renang, dll. Untuk obesitas, sasaran yang ingin dicapai adalah menurunkan berat badan 5$10 \%$ dari berat badan awal. Dengan penurunan berat badan $5-10 \%$ dari berat badan awal tersebut dapat mengurangi faktor resiko koroner. Sedangkan untuk berat badan kurang disarankan untuk melakukan perbaikan gizi diantaranya yaitu:

Perbaikan pola konsumsi makanan yang sesuai dengan gizi seimbang

1. Mengonsumsi makanan sesuai dengan standar angka kecukupan gizi

2. Mengonsumsi suplemen gizi yang ditujukan untuk memenuhi kecukupan gizi

\section{DAFTAR PUSTAKA}

1. Hariadi, Ali AR. Hubungan Obesitas Dengan Beberapa Faktor Risiko Penyakit Jantung Koroner. Jurnal Kesehatan. 2005;12(1):58-67.

2. Hermawan AG. Komplikasi Obesitas dan Usaha Penanggulangannya. Laboratorium Ilmu Penyakit Dalam Fakultas Kedokteran Universitas Sebelas Maret. CDK No. 68. Surakarta. 1991;1:39.

3. Sutjijoso AR, Zarfiel MD. Harga Diri Dan
Prestasi Belajar Pada Remaja Yang Obesitas. Jurusan Psikologi Universitas Indonesia Depok, Jawa Barat, Jurnal Psikologi . 2009;3(1):57.

4. Octari C, Liputo NI, Edison. Hubungan Status Sosial Ekonomi dan Gaya Hidup dengan Kejadian Obesitas pada Siswa SD Negeri 08 Alang Lawas Padang. Diambil dari: http://jurnal.fk.unand.ac.id, 26 Mei 2015.

5. Adam JMF, Adam FMS, Adrianjah $\mathbf{H}$. Penatalaksanaan Penderita Sindrom Metabolik. Medika Jurnal Kedokteran dan Farmasi. 2004;12:778-82.

6. Allo B, Syam A, Virani D. Hubungan Antara Pengetahuan Dan Kebiasaan Konsumsi Fast Food Dengan Kejadian Gizi Lebih Pada Siswa Sekolah Dasar Negeri Sudirman I Makassar. RSU Dok II Jayapura Provinsi Papua. Program Studi Ilmu Gizi Fakultas Kesehatan Masyarakat Universitas Hasanuddin, 2013.

7. Manurung NK. Pengaruh Karakteristik Remaja, Genetik, Pendapatan Keluarga, Pendidikan Ibu, Pola Makan dan Aktifitas Fisik Terhadap Kejadian Obesitas di SMU RK Tri Sakti Medan 2008 Medan: Universitas Sumatra Utara. 2009.

8. Notoatmodjo S. Promosi Kesehatan dan Kesahaan Perilaku. Bandung: Rineka Cipta, 2012. 